Neo-imperialism in solidarity organizations' public discourses: collective action frames, resources and audiences

Eugene Nulman ${ }^{1}$

Birmingham City University

The Curzon Building: 4 Cardigan Street Birmingham B4 7BD United Kingdom

01212028673

Dr Eugene Nulman is Senior Lecturer in Sociology at Birmingham City University. He is the author of the book Climate Change and Social Movements and has published academic articles in Current Opinion in Environmental Sustainability, Environmental Politics, Papers on Social Representations, and Media, Culture and Society. His research interests include social movements, political activism and political sociology.

${ }^{1}$ Email: Eugene.Nulman@bcu.ac.uk 


\title{
Abstract \\ Neo-imperialism in solidarity organizations' public discourses: collective action frames, resources and audiences
}

\author{
While neo-imperialism is becoming increasingly discussed within academia and by public \\ intellectuals this paper hypothesizes that due to resource needs of social movement \\ organizations, neo-imperialism is not be a major diagnostic frame used by international \\ solidarity organizations in the Global North. We tested this hypothesis by examining \\ diagnostic collective action frames used online by 30 organizations across three solidarity \\ movement issues: climate justice, refugee solidarity, and debt relief. While the frame was \\ infrequently used across the organizations, results reveal that those organizations that did \\ utilize the frame with some regularity had constituencies that have suffered from historical \\ forms of imperialism. A qualitative analysis was used to locate the contexts in which the \\ frame was used and the prominence these uses had within the organizations' public \\ broadcasting.
}

Keywords: social movement organizations; neo-imperialism; framing; climate justice; debt relief; refugee solidarity 


\section{Introduction}

Although by no means a new phenomenon, in recent years an increasing number of social movement organizations have formed in the Global North out of sympathy for those in the Global South. These sympathies, it is argued, arise out of 'conscious constituents' ${ }^{1}$ who take a view on solidarity expanding beyond borders. ${ }^{2}$ Such movements include those seeking climate justice, rights for refugees, and debt relief, among others. Such movements follow a long tradition of social movement work of allies, or "activists working for the benefit of groups to which they are outsiders", ${ }^{3}$ such as the abolition movement, the civil rights movement, and untouchability. ${ }^{4}$ It could be argued that these types of transnational solidarities mirror a growing "global consciousness that is making it increasingly difficult to view the "other" as inert... or as a helpless object of aid" ${ }^{5}$ while at the same time some have argued that "they can help disenfranchised and stigmatized groups gain access to greater material and political resources and may have an easier time appeal to mainstream audiences" ${ }^{6}$ Many solidarity movement organizations place the blame for problems that exist in the Global South on various institutions of the Global North (e.g. states, blocs, and international financial institutions) - often related to the countries in which the organizations were established. Despite widespread blame on these institutions, there are a wide variety of ways these organizations can present to the public the nature of the problem the Global South faces, the specific institutions which should be blamed, the relations between the North and the South, and the reason(s) why change should occur. Organizations' communication about these issues are referred to as their diagnostic collective action frames. ${ }^{7}$

Collective action frames are produced by social movement actors and function 'as articulation mechanisms in the sense of tying together the various punctuated elements of the scene so that one set of meanings rather than another is conveyed, or, in the language of narrativity, one story rather than another is told'. ${ }^{8}$ These frames can be presented to different audiences (e.g. movement targets, constituencies, the general public) in different ways and addressing different core framing tasks. Core framing tasks include an organization's statements about the problem they seek to address (diagnostic framing), how they plan to address it (prognostic framing) and the role individuals can play within a campaign and the reasons for individuals to engage with the movement (motivational framing). ${ }^{9}$ Frames allow observers to understand the reasons for an organization's claim-making and also to help legitimise the organization's identified concern. These frames need not be the organizations' own analysis of the diagnosis, as they can use frames strategically. ${ }^{10}$ That is, organizations can believe one thing but tell another story to the public, for example, in order to attract their attention and participation. Likewise, organizations can use multiple frames at the same time, linking several diagnoses together or in attempt to resonate with a diverse audience. ${ }^{11}$

As explained above, diagnostic framing is used to articulate the problem an organization seeks to address. Frames that operate across social movements are referred to as master frames. ${ }^{12}$ Neo-imperialism is one such frame which can be used to explain a wide range of problems in the Global South and thus can be used to explain the nature of a particular problem as part of a particular movement. Kwame Nkrumah wrote that the essence of neo-imperialism is that the State which is subject to it is, in theory, independent and has all the outward trappings of international sovereignty. In reality its economic system and thus its political policy is directed from outside'. ${ }^{13}$ Such a concept represents a systemic analysis of global relations capable of explaining a wide range of problems. 
This paper seeks to identify the extent to which solidarity movement organizations in the Global North shape their public discourse to include the use of the neo-imperialism master frame. This question is particularly interesting given the increasing prominence of neo-imperialism within postcolonial studies and international relations, ${ }^{14}$ as well as among public intellectuals and prominent figures. ${ }^{15}$ Such public discussions of neo-imperialism provides an opportunity for organizations to connect with these master frame in their own public-facing literature. Specifically, this paper will examine public webpages of organizations working on climate justice, refugee solidarity, and debt relief in different English speaking countries in the Global North to see the extent of the use of the neo-imperialism frame and understand the context of its use across a range of organizations within solidarity movements.

\section{Resource mobilization, framing and neo-imperialism}

While particular collective action frames can be informed by more dialogic communication between movement organizations and their audiences, framing itself involves a sender-recipient relationship whereby social movement actors produce frames that are encoded with meaning and distribute these messages for audiences to consume. ${ }^{16}$ Social movement organizations encode frames hoping that the audience decodes the messages through the organizations' preferred lens. ${ }^{17}$ Such distribution can occur through a range of media including speeches, banners, and websites. As a strategic practice, ${ }^{18}$ framing can seek to accomplish a variety of tasks including but not limited to mobilization, ${ }^{19}$ brand promotion, ${ }^{20}$ ideological alignment, ${ }^{21}$ and target persuasion. ${ }^{22}$ One key need for social movement organization is to accrue resources that they can utilize in their efforts at social change. This is a central tenet of resource mobilization theory and helps explain the decision-making of social movement organizations. ${ }^{23}$

According to resource mobilization theorists, resources that can be used by social movement organizations include human time, human effort, money, and infrastructure. ${ }^{24}$ The internet provide a new set of resources that can be utilized for some of the same purposes and can be less costly. In addition, different strategic approaches to achieving outcomes can require different levels of resourcing. ${ }^{25}$ Social movement organizations in the Global North may be hesitant to use the neoimperialism frame as it may limit the scope of audience for whom this frame would resonate with a public benefiting from the neo-imperial relation as it implies that, generally, those in the Global North benefit from exploitation of the Global South. Despite the increased discussion of neoimperialism by prominent figures as noted above, even those for whom the frame resonates may have an emotional response to the frame which is not beneficial to mobilizing human of financial resources. Such a frame has the potential to generate guilt, which is an emotion associated with demobilization within the social movement literature. ${ }^{26}$

Thus, we hypothesise that given the importance they place on mobilizing resources as a strategic focus - as supported by resource mobilization theory - Global North solidarity movement organizations will rarely utilize the neo-imperialism frame. However, as some publics in the Global North may have had detrimental experiences historically from colonialism (e.g. indigenous populations, the African diaspora) we expect to see organizations speaking with such audiences to be more likely to utilize the neo-colonialism frame as it should resonate more with these audiences.

When the neo-imperialism frame does appear, we will investigate its use by solidarity movement organizations. We will examine the following questions: 
- Which topics are discussed using the neo-imperialism frame?

- Are instances of these frames clustered or spread out across the websites?

- How prominently placed are these frames within the webpage?

- Are there patterns in how these neo-imperialism frames interact with others?

By answering these questions, we hope to establish greater knowledge of how these organizations, and perhaps others, are bringing this frame to the attention of the public through the persistent communication tool of organizational websites. While this may not mirror all means of communicating with the public, the ongoing and consistent presence of a website provides movement organizations with a clear, relatively resource-lite, and continuous space for broadcasting to the public. ${ }^{27}$

\section{Methodology}

The analysis consists of examining 10 English-language organizations in each of three issue areas: climate justice, refugee solidarity, and debt relief. The organizations were selected based on their prominence in their respective literatures ${ }^{28}$ and the existence of active or archived websites which provides thorough evidence of public communication and framing. While these organizations are not a perfect representative sample the fact that they are highlighted in their literatures is likely a sign of their prominence in those movements and/or their relative 'success' regarding mobilization rates, publicity or outcomes as these movement organizations are typically those highlighted in the literature. ${ }^{29}$

The organizations selected regarding climate justice were as follows: Climate Justice Action (CJA), Earth in Brackets, Grassroots Global Justice Alliance (GGJ), Global Justice Ecology Project (GJEP), Indigenous Environmental Network (IEN), Mobilization for Climate Justice (MCJ), Powershift Canada, Rising Tide North America, Rising Tide UK, and Southwest Network for Environmental and Economic Justice (SNEEJ). For refugee solidarity, the organizations selected were Boats4People, Breaking Barriers, Care4Calais, Calais Refugee Solidarity Bristol (CRSB), Refugee Action Coalition (RAC), Refugee and Migrant Solidarity Ireland (RAMSI), Refugee Action, Refugees Welcome, Student Action for Refugees (STAR), Solidarity with Refugees UK (SWRUK). For debt relief, the analysed organizations consisted of Committee for the Abolition of Illegitimate Debt (CADTM), Debt and Development Coalition Ireland (DDCl), European Network on Debt and Development (Eurodad), Jubilee Australia, Jubilee Scotland, Jubilee UK, Jubilee USA, Make Poverty History (MPH), ONE, and Oxfam Canada (see Table 1).

\section{[Insert Table 1]}

For the purpose of analysing frames directed at the public, websites are an excellent source of information. ${ }^{30}$ While they do not represent the organizations' breadth and scope of work or ideas, publicly-visible websites function as places where the organizations can broadcast information to the public, as well as facilitating dialogic communication with their audiences. ${ }^{31}$ The webpages of websites for all organizations were collected and imported into NVivo. ${ }^{32}$ Some organizations' websites also included portable document format files (PDFs) of materials meant for public distribution. These too were added to documents being coding. Keeping in line with the mission of this research project, only texts that were public-facing, authored by the organization and its representatives, and pertained to climate justice, refugee solidarity, debt relief - respectively - were used for analysis. Thus, as some organization were also involved in other campaigns or issues (e.g. Oxfam Canada), only webpages related to the relevant issue were included. 
Once the webpages were collected and imported into NVivo they were manually coded in relation to diagnostic frames. Frames represented nodes and were constructed inductively from the data (webpages). Coding was attributed to the unit of analysis (sentences) within the texts (webpages). Once coded the data was re-examined to check for errors of miscoding or missed coding. Frames were constructed on an issue (climate justice, refugee solidarity or debt relief) basis. Thus 14, 13, and 15 nodes were used to understand the organizations' diagnostic frames for an issue that regards the Global South for the three issues, respectively. This includes the master frame of neo-imperialism, which states that the root of the problem stems from ongoing imperialism that is a product of an unequitable distribution of power within a global capitalist system. The other diagnostic frames for each issue can be found in Tables 2, 3 and 4 .

[Insert Table 2]

[Insert Table 3]

[Insert Table 4]

These codes were attributed on a sentence-by-sentence basis inclusive of titles and subtitles where relevant, along with the bodies of texts. Some sentences incorporated more than one frame, thus being coded at multiple nodes. Each page was then classified into their respective organizations. The examination of the diagnostic frames included 68 texts for climate justice organizations, 138 for refugee solidarity organizations, and 246 for debt relief organizations, each of various lengths. A Matrix Coding query was run producing a table involving organizations ( $N=10$ for each issue) and nodes at which parts of webpage texts were coded. The level of coding varied across texts. The organizations examined for each issue and a summary of the coding is presented below. Data was analysed using descriptive statistics where relevant and was further examined using a qualitative form of content analysis in order to answer the research question at hand, following a pragmatic research design ${ }^{33}$

\section{Climate justice}

The examination of diagnostic frames among climate justice organizations resulted in 1069 individual instances of coding across 68 texts. This resulted in an average of over 15 references per text. The data show that while the average number of references per node (frame) is 71.3 there is a standard deviation of 81.2 references, within a minimum of 7 (elites) and a maximum of 323 ('false solutions') (see Figure 1).

\section{[Insert Figure 1]}

\section{Refugee solidarity}

The data for refugee solidarity organizations included 1,599 codes of diagnostic frames instances of 138 texts (average $=11.6$ references per text). The results show that the average number of references per node (frame) is 123 ( $S D=128.0$; $\max =474$ (national government responsibility); minimum $=0$ (neo-imperialism) (see Figure 2 ). One thing to note is the similarities across organizations not only with placing responsibility on the doorstep of government but the ways in which they discuss the danger and vulnerability faced by refugees and the ineffectiveness of dealing with this humanitarian crisis.

\section{[Insert Figure 2]}




\section{Debt relief}

The number of individual instances of coding across the 246 texts for debt relief organizations was 2,837 (average $=11.5$ references per text). The results show that while the average number of references per node (frame) is 189.1 there was a high standard deviation (SD = 129.2; $\max =462$ (living conditions poor); minimum = 21 (neo-imperialism) (see Figure 3). Most frames appeared at least once across a vast majority of the ten debt relief organizations with the frames appearing in the least number of organizations' texts appearing in seven of ten (neoimperialism and neoliberal capitalism). Across organizations, focus was often placed on international financial institutions, the living conditions of those in debtor countries, and injustice. Debt relief organizations had the most variance across frames within each organization, meaning they used many frames to discuss their diagnosis of the problem. However, this could have been due to the larger sample size of coded texts.

\section{[Insert Figure 3]}

Once coded, instances of the neo-imperialism frame were highlighted and examined qualitatively across all relevant webpages and organizations. Patterns were sought for the topics for which the frame was used, the frames clustering on websites, the prominence of their placement, and their relations to other frames within the public texts.

\section{Results}

We predicted that the neo-imperialism frame is used only rarely by solidarity movement organizations in the Global North and argued that this was the case due to a strategic need for resources, both human and financial, from sources within the Global North. The results show that across the thirty organizations and three issues, the neo-imperialism frame was only used a total of 75 times out of a total of 5,505 diagnostic frame nodes. Only 31 of the 452 webpages examined included the neo-imperialism frame. Of course these numbers differed across the three movement issues. Despite the relatively low number of texts and nodes, climate justice organizations were recorded as having the greatest number of nodes regarding neo-imperialism (54) while the refugee solidarity organizations made no reference to neo-imperialism. The debt relief organizations included 21 instances of the frame. The differences were also visible across organizations. It is worth exploring these instances of neo-imperialism framing in more detail as they are not all alike and they appear disproportionately across a relatively small number of organizations. Twelve organizations, of thirty, utilized the neo-imperialism frame, albeit infrequently. These twelve organizations totalled 2454 diagnostic framing nodes, so neo-imperialism played only a small role in the overall diagnostic story - confirming our hypothesis that the frame would only be used occasionally. But assuming not all nodes are equal because of their position within the organizations' websites we can investigate just how important the frame was for these organizations using more in-depth qualitative analysis.

\section{Climate justice}

Analysis from the 68 texts across 10 climate justice organizations resulted in 54 instances of the use of the neo-imperialism frame. These uses occurred across five organizations. A large proportion of these frames discussed an emerging form of neo-imperialism coming out of the negotiations for mitigating climate change. 
For example, in Africa, REDD+ [reduce emissions from deforestation and forest degradation, etc..], carbon credits, agrofuels and export crops, are driving huge land grabs.... In Africa, REDD+ is emerging as a new form of colonialism, economic subjugation and a driver of land grabs so massive that they may constitute a continent grab. ${ }^{34}$

Such a position on neo-imperialism reflects broader discussions of the trajectory of neoimperialism, as found in this quote:

On the developmental side of North - South relations there is, however, now a need for justifications of overtly or covertly emerging forms of neo-imperialism or neo-imperialism to be based on something different from the traditional arguments regarding civilisational superiority and inferiority. At the very least, such arguments must be made more palatable, by appealing in a more sophisticated manner to the need for external solutions to (post)colonial problems. ${ }^{35}$

Indeed, the IEN has stated, on the subject of the various 'solutions' to climate change proposed at international climate change negotiations, that:

Just as historically the Doctrine of Discovery was used to justify the first wave of colonialism by alleging that Indigenous Peoples did not have souls, and that our territories were 'terra nullius,' land of nobody, now these green economy initiatives such as California REDD and other REDD+ projects are inventing similarly dishonest premises to justify this new wave of colonialization and privatization of nature. ... Regardless of its cynical disguises and shameful lies, colonialism always results in the rape and pillaging of Mother Earth, and the slavery, death, destruction and genocide of her economy models of commodification and trading of ecosystem services constitutes a thinly-veiled, wicked, colonialist planet grab that we oppose, denounce and resist. ${ }^{36}$

Rising Tide UK also made similar statements regarding such 'solutions', particularly carbon markets. They stated that such solutions 'continue a pattern of neo- colonial exploitation of the Third World with the rich world controlling large new speculative markets in carbon credits. These carbon trading markets are therefore an extension of the north dominated control of global finance'.$^{37}$ In the Rising Tide Coalition for Climate Justice Political Statement they also reiterated this point, calling carbon markets 'a form of modern-day colonialism'. ${ }^{38}$

This focus on problems with current solutions to climate change represented a majority of uses of the neo-imperialism frame among climate justice organizations (42 of 54). The frame was also used in conjointly with discussions of inequality and anti-capitalism (Climate Justice Action), corporations (GGJ, GJEP and IEN) and climate racism and indigenous rights (IEN). Fewer references were made to the problem of climate change resulting from an economic system of neo-imperialism. Such references accounted for three instances throughout the texts. For example:

Climate justice means addressing the inequalities that exist between and within countries, and replacing the economic and political systems that uphold them. The status quo is maintained through unequal exchange via unjust trade policies and unequal access to technological capacity. On a global level Europe is a centre of capital accumulation and thus socio-ecological exploitation of the South.... ${ }^{39}$

Another variant of the neo-imperialism frame discussed the United States of America specifically as 'the empire', placing blame within those (three) passages on the country and its support for free trade and associated institutions, one of which discussed its 'naked imperial ambition' ${ }^{40}$ The remaining uses were ambiguous in their meaning but directly named 'empire' or 'neo-imperialism' as an explanation for climate injustice. 
While the frame was utilized relatively rarely among climate justice organizations, it was not without importance for these organizations. Both GGJ and GJEP featured the neo-imperialism frame in their 'About' pages and IEN - the organization that utilized the frame the most number of times (Table 5) - had incorporated the frame in 7 of 11 webpages.

[Insert Table 5]

\section{Debt relief}

For debt relief organizations, seven of 10 used the neo-imperialism frame at least once. One organization, CADTM, stands out above the rest, although even here neo-imperialism accounted for a fraction of all the organization's diagnostic frames. CADTM used messaging relating to neoimperialism 12 times, out of the 403 nodes that were coded across all examined webpages for the organization. Regarding the frame in question, CADTM (2009) repeatedly discussed debts as 'a subtle mechanism of domination and a new method of colonization', often referring to the notion of 'economic re-colonisation' ${ }^{41}$ and even as a 'modern form of slavery'. ${ }^{42}$ These mentions were often discussed in direct relation to IFIs or structural adjustment programs. The uses of the frame were also found in important aspects of the organizations website, namely it's 'About' page and in its political charter.

Other organizations which used the frame only used it sparsely (Table 6) - no more than twice across their website. However, like CADTM these organizations were often very explicit with their discussion of neo-imperialism. The DDCl said, in one webpage (quoting Jubilee South) 'the wealth of the North has been accumulated largely at the expense of the South'. ${ }^{43}$ but this was their only reference despite Ireland's own history of subjugation. One of two of Jubilee USA references to neoimperialism discussed 'a new age of economic imperialism and colonialism' ${ }^{44}$ and both of ONE's references discussed debt as a form of 'modern-day apartheid'. ${ }^{45}$ Across these organizations, references to neo-colonialism tied closely to IFIs such as the International Monetary Fund and the World Trade Organization. In addition, the nine references by organizations other than CADTM were featured on webpages not centrally displayed on the organizations' websites and often toward the bottom of the webpage. One reference did correspond to the title of a webpage but as a direct quote by Desmond Tutu. ${ }^{46}$ Interestingly, of the nine references, four were quotations. This included one from the Financial Times which described the relationship between 'European institutions' and debtor countries as 'akin to the relationship between a colonial overlord and its vassal'. ${ }^{47}$

[Insert Table 6]

Regarding the clustering of these references, CADTM's eleven references appeared across eight webpages while the nine references found across all other debt-relief organizations, clustered around six webpages. That is, the six other organizations that utilized a neo-imperialism diagnostic frame did so only on a single webpage. Even if the frame appeared more than once, these organizations did not utilize the frame in different digital spaces of their websites. While this qualitative data is interesting, from a quantitative perspective the neo-imperialism frame was utilized in relatively few instances. What is demonstrated with the use of the frame is that a neoimperialism perspective on the problems being addressed by these organizations were known and understood but not heavily relied upon when communicating with publics. However, as was also hypothesized, the organizations with the largest number of the neo-imperialism frames were those organizations whose constituencies represented communities who also suffered from colonialism 
and imperialism. IEN is an organization explicitly oriented around indigenous issues, including climate justice. They included 35 references to neo-imperialism in a majority of the webpages examined. Likewise, GGJ highlights the importance of indigenous and minority communities in their organization, stating that they "work across issues and regions to develop agendas by and for working-class people, poor people, indigenous people and communities of color" ${ }^{48}$ In addition CADTM - with 12 references, the most among debt relief organizations - operates as a network of local committees across communities including those in Latin America, Africa and Asia. ${ }^{49}$ Thus, organizations with high-levels of use of the neo-imperialism frame did closely engage with communities negatively impacted historically by imperialism but not all organizations with such engagement utilized the frame. Organizations such as Boats4People, which operates across European and African countries, did not utilize the neo-imperialist frame.

\section{Conclusion}

The findings appear to indicate that solidarity movement organizations in the Global North only infrequently used notions of neo-imperialism in framing the problem they sought to address, despite often placing blame on or targeting institutions of the Global North. Of the thirty organizations examined only 12 had used the neo-imperialism frame across the texts examined. Even those 12 organizations rarely used the frame, just 75 times out of a total 5,505 instances of diagnostic framing. This rare use of the frame, despite its relative widespread appearance within popular discourses, could be explained through resource mobilization theory, which argues that organizations accumulate and utilize resources as a central function of social movement activity. If the social movement leaders that wield decision-making power within organizations deem the use of the neo-imperialism frame as not strategic when calculating the resource benefits, resource mobilization theory suggests that they may be less likely to use it.

However, the frame was used more frequently and centrally across some organizations. These organizations, namely IEN, GGJ and CADTM, used their website to communicate to constituencies that may have historically experienced the negative effects of imperialism. As those communities may have been more likely to resonate with such a frame, its greater use is still predicted by resource mobilization. This is unlike many of the refugee solidarity organizations that were often using their website to communicate with communities in the Global North, rather than the refugees who they sought to support through their activism. Among these organizations, no references were made to neo-imperialism frame.

The neo-imperialist frame was invoked by some climate justice organizations often when discussing 'false solutions' to climate change such as carbon markets. The frames were also paired with discussions of indigenous rights and putting the blame on corporations or IFIs. For debt relief organizations, the uses of the neo-imperialism frame were largely found in one organization, CADTM, or on one webpage for several other organizations. Thus, such frames were not prevalent even amongst organizations where the frame appeared, and the frame appeared often in the form of quotations taken from others - putting the organization at an arm's length from the frame. This was untrue for CADTM, who typically directed the frame at the ways IFIs imposed themselves on countries of the Global South through debts, often referring to the use of structural adjustment programs.

While we have demonstrated here that the neo-imperialism frame is rarely used across a range of organizations within a broader solidarity movement, some organizations did utilize the 
frame openly and actively in their public communications online. These organizations were those that had constituencies beyond either just those individuals in the Global North or including communities in the Global North who experienced negative consequences of previous forms of imperialism. The findings support resource mobilization theory. However, the findings do not demonstrate a causal link between these organizations' uses of neo-imperialism as a frame in public communication. Such causal links could be investigated with in-depth qualitative research exploring the strategic leadership capacities ${ }^{50}$ and strategies of the organizations in question in order to better understand how such communication is strategically discussed at the organizational level.

\section{Notes}

${ }^{1}$ Olesen, International Zapatismo, 33.

${ }^{2}$ Ibid., 38.

${ }^{3}$ Myers, "Ally Identity," 167. Also see Marx and Useem, "Majority Involvement in Minority Movements."

${ }^{4}$ See e.g. Marx and Useem, "Majority Involvement in Minority Movements." McAdam, Freedom Summer.

${ }^{5}$ Olesen, International Zapatismo, 38.

${ }^{6}$ Russo, "Allies Forging Collective Identity," 68.

${ }^{7}$ Benford and Snow, "Framing Processes and Social Movements."

${ }^{8}$ Snow, "Framing Processes, Ideology, and Discursive," 384.

9 Benford and Snow, "Framing Processes and Social Movements."

${ }^{10}$ Zald, "Culture, Ideology and Strategic Framing."

${ }^{11}$ See Rao, Morrill and Zald, "Power Plays."

${ }^{12}$ Carroll and Ratner, "Master Framing and Cross-Movement Networking."

${ }^{13}$ Nkrumah, Neo-imperialism, ix.

${ }^{14}$ E.g. Young, Postcolonialism; Baylis et al, Globalization of World Politics; Daddow, International Relations Theory.

${ }^{15}$ Chomsky, Year 501; Pope Francis, "Speech at World Meeting of Popular Movements;" Klein

"Climate Change Is a People's Shock."

${ }^{16}$ Olesen, International Zapatismo, 30.

${ }^{17}$ Hall, "Encoding/decoding."

${ }^{18}$ Ganz, "Why David Sometimes Wins;" Jasper, "Strategic approach to collective action."

${ }^{19}$ Snow et al, "Frame Alignment Processes."

${ }^{20}$ Gamson, "Constructing Social Protest."

${ }^{21}$ Oliver and Johnston, "What a Good Idea!"

${ }^{22}$ Nulman, "Climate Change and Social Movements."

${ }^{23}$ McCarthy and Zald, "Resource Mobilization and Social Movements."

${ }^{24}$ Edward and McCarthy, "Resources and Social Movement Mobilization."

${ }^{25} \mathrm{Kolb}$, Protest and Opportunities.

${ }^{26}$ Flam, "Emotions' map."

${ }^{27}$ Nulman and Özkula, "Environmental governmental organizations' digital media practices toward environmental sustainability and implications for informational governance."

${ }^{28}$ For the climate justice organizations see: Bond, "Climate governance;" Bond and Dorsey, "Anatomies of Environmental Knowledge \& Resistance;" Chatterton and Routledge, "Articulating Climate Justice;" Choy and Orozco, "Chevron in Richmond;" Dayaneni, "Carbon Fundamentalism vs. 
Climate Justice;" Demos, "Contemporary Art and the Politics of Ecology;" Foran, iVolveremos!; Guerrero, "US social forum;" Gulliver and Herriot, "Arab Spring;" Schlosberg and Carruthers, "Indigenous Struggles;" Schlosberg, "Networks and mobile arrangements;" Stabinsky, "Teaching and Practicing Climate Politics;" Tokar, "Movements for Climate Justice." For refugee solidarity see: Gosden, "What Can Ordinary People Do?;" Irish Refugee Council, "Open up safe and legal access;" Koca, "New Social Movements;" Nunn, "Magnificent response;" Pujol-Mazzini, "Fear of refugees rises;" Pupavac, "Refugee Advocacy;" Rygiel, "In Life Through Death;" Tazreiter, "Local to Global Activism;" Woodcraft, "March with Woodcraft for Refugees;" Zetter and Pearl, "Minority within the minority." For debt relief, see: Ambrose, "Politics of Debt Cancellation;" Arvanitakis, "Surviving NeoLiberalism;" Hinojosa et al., "Contesting unfair international capitalism;" Nakatani and Herrera, "South Has Already Repaid;" Nash, "Global Citizenship as Showbusiness;" Sachs, The End of Poverty; Saner and Yiu, "Business - Government - NGO Relations;" Van Rooy, "Good news!;" Wisner, "Untapped potential."

${ }^{29}$ Nulman, "The policy impact of climate change activism in the UK."

${ }^{30}$ Stein, "Social movement web use in theory and practice."

${ }^{31}$ Nulman and Özkula, "Environmental governmental organizations' digital media practices toward environmental sustainability and implications for informational governance."

${ }^{32}$ It should be noted that MJC, CJA, and SNEEJ had websites that are not presently available but webpage data was collected via digital internet archives (Wayback Machine and Archive.is) which stored limited webpages leading to a loss of data for those organizations.

${ }^{33}$ Tashakkori and Teddlie, Mixed Methodology, 20-39.

${ }^{34}$ Coordinating Committee of the Global Alliance of Indigenous Peoples and Local Communities on Climate Change against REDD+ and for Life, "Global Alliance of Indigenous Peoples."

${ }^{35}$ Andreasson, "Orientalism and African Development Studies," 975.

${ }^{36}$ Coordinating Committee of the Global Alliance of Indigenous Peoples and Local Communities on Climate Change against REDD+ and for Life, "Global Alliance of Indigenous Peoples."

${ }^{37}$ Rising Tide UK, "The international negotiations."

${ }^{38}$ Rising Tide UK, "The Rising Tide Coalition for Climate Justice Political Statement."

${ }^{39}$ Climate Justice Action, "What does climate justice mean in Europe."

${ }^{40}$ Grassroots Global Justice, "Briefing Paper for Lessons of Trade Campaigns Meeting."

${ }^{41}$ CADTM, "About CADTM."

${ }^{42}$ Toussaint, "The World Bank: a never-ending coup d'état."

${ }^{43} \mathrm{DDCl}$, "Co-responsibility of failed loans."

${ }^{44}$ Jubilee USA, "Islam \& Economic Justice."

${ }^{45}$ ONE Partners, "Desmond Tutu."

${ }^{46} \mathrm{lbid}$.

47 Jubilee Debt Campaign, "The Never-Ending Austerity Story."

${ }^{48}$ Grassroots Global Justice, "About GGJ."

${ }^{49}$ CADTM, "About CADTM."

${ }^{50}$ Ganz, "Why David Sometimes Wins."

\section{References}

Ambrose, S. "Social Movements and the Politics of Debt Cancellation." Chicago Journal of International Law 6, no. 1 (2005): 267-285.

Van Rooy, A. "Good news! You may be out of a job: reflections on the past and future 50 years for Northern NGOs." In Debating Developing: NGOs and the Future, edited by D. Eade and E.

Ligteringen, 19-43. Oxford: Oxfam, 2001. 
Andreasson, S. "Orientalism and African Development Studies: the 'reductive repetition' motif in theories of African underdevelopment", Third World Quarterly 6, n. 26 (2005): 971-986.

Arvanitakis, J. "Surviving Neo-Liberalism: NGOs Under the Howard Years", Nebula 6, n. 3 (2009): 5369.

Baylis, J, S. Smith, and P. Owens. The Globalization of World Politics: An Introduction to International Relations, Sixth Edition. Oxford: Oxford University Press, 2014.

Benford, R. D., and D. A. Snow. "Framing Processes and Social Movements: An Overview and Assessment." Annual Review of Sociology 26, (2000): 611-639.

Bond, P. "Climate governance according to ideals of justice." Paper presented the symposium of Climate Governance in the Post-Copenhagen Era: New Directions in Policy Practice and Scholarship, Linköping University, May 8, 2014.

http://ccs.ukzn.ac.za/files/Bond\%20Climate\%20governance\%20according\%20to\%20ideals\%20of\%20 justice.pdf.

Bond, P., and M. K. Dorsey. "Anatomies of Environmental Knowledge \& Resistance: Diverse Climate Justice Movements and Waning Eco-Neoliberalism." The Journal of Australian Political Economy 66, (2010): 286-316.

CADTM. "About CADTM." 2007. http://www.cadtm.org/About-CADTM.

CADTM. "60 Questions on the IMF-World Bank and the Debt Scam." 2009.

http://www.cadtm.org/60-Questions-on-the-IMF-World-Bank

Carroll, W. K., and R. S. Ratner. "Master Framing and Cross-Movement Networking in Contemporary Social Movements." The Sociological Quarterly 37, n. 4 (1996): 601-625.

Chatterton, P., and P. Routledge. "Articulating Climate Justice in Copenhagen: Antagonism, the Commons, and Solidarity." Antipode 45, n. 3 (2013): 1-19.

Chomsky, N. Year 501: The Conquest Continues, Montreal: Black Rose Books, 1993.

Choy, E., and A. Orozco. "Chevron in Richmond: Community-Based Strategies for Climate Justice." Race, Poverty and the Environment 16, n. 2 (2009): 43-46.

Climate Justice Action. "What does climate justice mean in Europe?." Wayback Machine.

https://web.archive.org/web/20110223195805/http://www.climate-justiceaction.org/resources/documents/what-does-climate-justice-mean-in-europe/.

Coordinating Committee of the Global Alliance of Indigenous Peoples and Local Communities on Climate Change against REDD+ and for Life. "Global Alliance of Indigenous Peoples and Local Communities on Climate Change against REDD+ and for Life." Indigenous Environmental Network. 2013. http://www.ienearth.org/global-alliance-of-indigenous-peoples-and-local-communities-onclimate-change-against-redd-and-for-life/

Daddow, O. International Relations Theory: The Essentials, $2^{\text {nd }}$ Edition, London: SAGE, 2013.

Dayaneni, G. "Carbon Fundamentalism vs. Climate Justice." Race, Poverty, and the Environment (2009): 7-11.

DDCI. “Co-responsibility of failed loans." http://www.debtireland.org/issues/debt/coresponsibility.html 
Demos, T. J. "Contemporary Art and the Politics of Ecology: An Introduction." Third Text 27, n. 1 (2013):1-9.

Edwards, B., and J. D. McCarthy. "Resources and Social Movement Mobilization." In The Blackwell Companion to Social Movements, edited by D. A. Snow, S. A. Soule and H. Kriesi, 116-152. Malden: Blackwell, 2004.

Foran, J. "'¡Volveremos! / we will return': The state of play for the global climate justice movement." Interface 6, n. 1 (2014): $454-477$.

Flam, H. "Emotions' map: a research agenda." In Emotions and Social Movements, edited by H. Flam and D. King, 19-40. London: Routledge, 2005.

Gamson, W. A. "Constructing Social Protest." In Social Movements and Culture, edited by H. Johnston and B. Klandermans, 85-106. Minneapolis: University of Minnesota Press, 2004.

Ganz, M. "Why David Sometimes Wins: Strategic Capacity in Social Movements." In Rethinking Social Movements: Structure, Meaning and Emotion, edited by J. Goodwin and J. M. Jasper, 177-198. Oxford: Rowman \& Littlefield, 2004.

Gosden, D. "What Can Ordinary People Do? Reflections on advocacy." Migration Action 27, n. 3 (2005): 26-32.

Grassroots Global Justice, “About GGJ.” http://ggjalliance.org/about

Grassroots Global Justice, "Briefing Paper for Lessons of Trade Campaigns Meeting." 15 October, 2005. http://ggjalliance.org/sites/default/files/GGJBriefingPaperFall05.doc

Guerrero, M. L. "The US social forum: Building from the bottom up." In The World and US Social Forums: A Better World Is Possible and Necessary, edited by J. Blau and M. Karides, 21-40. Leiden: Brill, 2008.

Gulbrandsen, L. H., and S. Andersen. "NGO Influence in the Implementation of the Kyoto Protocol: Compliance, Flexibility Mechanisms, and Sinks." Global Environmental Politics 4, n. 4 (2004): 54-75.

Gulliver, T., and L. Herriot. "'Some Liken it to the Arab Spring': Youth and the Politically Legitimate Subject." Critical Discourse Studies 12, n. 2 (2015):206-225.

Hall, S. "Encoding/decoding." In Culture, Media, Language, edited by S. Hall, D. Hobson, A. Lowe and P. Willis, 117-127. New York: Taylor \& Francis, 2005.

Hinojosa, L., D. Pearce, and S. Dumpleton. "Contesting unfair international capitalism: Assessment of the effectiveness and impact of campaigning and advocacy from the NGO sector." Brooks World Poverty Institute Working Paper 2. 2007.

http://hummedia.manchester.ac.uk/institutes/gdi/publications/workingpapers/bwpi/bwpi-wp0207.pdf.

Irish Refugee Council. "Open up safe and legal access to Ireland for refugees, says Irish Refugee Council." 2016. http://www.irishrefugeecouncil.ie/news/open-up-safe-and-legal-access-to-irelandfor-refugees-says-irish-refugee-council/5018.

Jasper, J. M. "A strategic approach to collective action: Looking for agency in social-movement choices." Mobilization: An International Quarterly 9, n. 1 (2004): 1-16. 
Jubilee Debt Campaign. "The Never-Ending Austerity Story." 2016 http://jubileedebt.org.uk/wpcontent/uploads/ShortpixelBackups/2016/05/1602-Greece-briefing-FINAL.pdf

Jubilee USA. "Islam \& Economic Justice." http://www.jubileeusa.org/faith/islamic-resources/islamand-economic-justice.html

Klein, N. 2014. "Climate Change Is a People's Shock." The Nation, September 16.

https://www.thenation.com/article/climate-change-peoples-shock/.

Koca, B. T. “New Social Movements: 'Refugees Welcome UK'." European Scientific Journal, 12, n. 2 (2016): 96-108.

Kolb, F. Protest and Opportunities: The Political Outcomes of Social Movements, Frankfurt: Campus Verlag, 2007.

Marx, G. and M. Useem. "Majority Involvement in Minority Movements: Civil Rights, Abolition, Untouchability." Journal of Social Issues, 82, n. 6 (1971): 81-104.

McAdam, D. Freedom Summer. New York: Oxford University Press, 1988.

McCarthy, J. D., and M. N. Zald. "Resource Mobilization and Social Movements: A Partial Theory." American Journal of Sociology 82, n. 6, (1997):1212-1241.

Myers, D. J. "Ally Identity: The Politically Gay." In Identity Work in Social Movements, edited by J. Reger, D. J. Myers, and R. L. Einwohner, 167-188. Minneapolis: University of Minnesota Press, 2008.

Nakatani, P., and R. Herrera. "The South Has Already Repaid its External Debt to the North: But the North Denies its Debt to the South." Monthly Review 59, n. 2 (2007): 31-36.

Nash, K. "Global Citizenship as Showbusiness: The Cultural Politics of Make Poverty History." Media, Culture and Society, 30, n. 2 (2008): 167-181.

Nkrumah, K. Neo-imperialism, the Last Stage of Imperialism. International Publishers: New York, 1966.

Nulman, E. Climate Change and Social Movements: Civil Society and the Development of National Climate Change Policy. New York: Palgrave Macmillan, 2015.

Nulman, E. The policy impact of climate change activism in the UK. PhD Thesis. University of Kent, 2014.

Nulman, E, and Özkula, S. M. “Environmental governmental organizations' digital media practices toward environmental sustainability and implications for informational governance." Current Opinion in Environmental Sustainability, 18, (2016): 10-16

Olesen, T. International Zapatismo: The Construction of Solidarity in the Age of Globalization. New York: Zed Books, 2005.

Oliver, P. E., and H. Johnston. "What a Good Idea! Frames and Ideologies in Social Movement Research". Paper presented at the annual meeting of the American Sociological Association, Chicago. August 8, 1999.

http://www.ssc.wisc.edu/ oliver/PROTESTS/ArticleCopies/Frames.2.29.00.pdf

ONE Partners. "Desmond Tutu: Debt is Modern-Day Apartheid." ONE. 2008.

https://www.one.org/international/blog/desmond-tutu-debt-is-modern-day-apartheid/ 
Pujol-Mazzini, A. 2016. "As fear of refugees rises, photo exhibition aims to turn positive lens on their lives." Thomson Reuters Foundation, July 13. http://news.trust.org/item/20160713153620-msnfu.

Pope Francis. 2015. "Speech at World Meeting of Popular Movements." Radiovaticana. July 9. http://en.radiovaticana.va/news/2015/07/10/pope francis speech at world meeting of popular movements/1157291/.

Nunn, L. 2015. "Magnificent response in Bristol to Calais Refugee Solidarity Campaign." RS21, September 26. https://rs21.org.uk/2015/09/26/magnificent-response-in-bristol-to-calais-refugeesolidarity-campaign/.

Pupavac, V. "Refugee Advocacy, Traumatic Representations and Political Disenchantment." Government and Opposition 43, n. 2 (2008): 270-292.

Rao, H., C. Morrill, and M. N. Zald. "Power Plays: How Social Movements and Collective Action Create New Organizational Forms." Research in Organizational Behaviour, 22, (2000): 237-281.

Rising Tide UK. "The international negotiations." N.D.

https://risingtide.org.uk/resources/factsheets/international

Rising Tide UK, "The Rising Tide Coalition for Climate Justice Political Statement." N.D.

https://www.risingtide.org.uk/about/political

Russo, C. "Allies Forging Collective Identity: Embodiment and Emotions on the Migrant Trail." Mobilization: An International Quarterly 19, n.1 (2014): 67-82.

Rygiel, K. "In Life Through Death: Transgressive Citizenship at the Border." In Routledge Handbook of Global Citizenship Studies, edited by E. F. Isin, and P. Nyers, 62-72. London: Routledge, 2014.

Sachs, J. D. The End of Poverty: Economic Possibilities for Our Time, New York: Penguin Books, 2015.

Saner, R., and L. Yiu. "Business - Government - NGO Relations: Their Impact on Global Economic Governance." In Global Governance and Diplomacy: Worlds Apart?, edited by A. F. Cooper, B. Hocking, and W. Maley, 85-103. Baskingstoke: Palgrave MacMillan, 2008.

Schlosberg, D. "Networks and mobile arrangements: organisational innovation in the US environmental justice movement." Environmental Politics 8, n. 1 (1999): 122-148.

Schlosberg, D., and D. Carruthers. "Indigenous Struggles, Environmental Justice, and Community Capabilities." Global Environmental Politics 10, n. 4 (2000): 12-35.

Snow, D. "Framing Processes, Ideology, and Discursive Fields." In The Blackwell Companion to Social Movements, edited by D. A. Snow, S. A. Soule, H. Kriesi, 380-413. Malden: Blackwell, 2006.

Snow, D. A., E. B. Rochford Jr., S. K. Worden, and R. D. Benford. "Frame Alignment Processes, Micromobilization and Movement Participation." American Sociological Review 51, n. 4 (1986): 546481.

Stabinsky, D. "Teaching and Practicing Climate Politics at College of the Atlantic: Student-inspired, Student-driven." Radical Teacher 102, (2015):24-29.

Stein, L. "Social movement web use in theory and practice: A content analysis of US movement websites." New Media \& Society 11, n. 5 (2009): 749-771. 
Tashakkori, A., and C. Teddlie. Mixed Methodology: Combining Qualitative and Quantitative Approaches, Thousand Oaks: SAGE Publications, 1998.

Tazreiter, C. "Local to Global Activism: The Movement to Protect the Rights of Refugees and Asylum Seekers." Social Movement Studies 9, n. 2 (2010): 201-214.

Tokar, B. "Movements for Climate Justice in the US and Worldwide." In Routledge Handbook of the Climate Change Movement, edited by M. Dietz and H. Garrelts, 131-146. Abingdon: Routledge, 2014.

Toussaint, E. "The World Bank: a never-ending coup d'état: The hidden agenda of the Washington Consensus." www.cadtm.org/The-World-Bank-a-never-ending-coup.

Wisner, R. "Untapped potential of the world's religious communities for disaster reduction in an age of accelerated climate change: An epilogue \& prologue." Religion 40, (2010): 128-131.

Woodcraft. "March with Woodcraft for Refugees." https://www.woodcraft.org.uk/news/marchwoodcraft-refugees.

Young, R. J. C. Postcolonialism: An Historical Introduction, Malden, MA: Blackwell, 2004.

Zald, M. N. "Culture, Ideology and Strategic Framing." In Comparative Perspectives on Social Movements: Political Opportunities, Mobilizing Structures and Cultural Framings, edited by D. McAdam, J. D. McCarthy and M. N. Zald, 261-274. Cambridge: Cambridge University Press, 1999.

Zetter, R., and M. Pearl. "The minority within the minority: Refugee community-based organisations in the UK and the impact of restrictionism on asylum-seekers." Journal of Ethnic and Migration Studies 26, n. 4 (2000):675-697. 
Table 1 - Selected organizations

\begin{tabular}{|c|c|c|}
\hline Climate Justice & Refugee Solidarity & Debt Relief \\
\hline CJA & Boats4People & CADTM \\
\hline $\begin{array}{c}\text { Earth in } \\
\text { Brackets }\end{array}$ & Breaking Barriers & DDCI \\
\hline GGJ & Care4Calais & Eurodad \\
\hline GJEP & CRSB & Jubilee Australia \\
\hline IEN & RAC & Jubilee Scotland \\
\hline MCJ & RAMSI & Jubilee UK \\
\hline $\begin{array}{c}\text { Powershift } \\
\text { Canada }\end{array}$ & Refugee Action & Jubilee USA \\
\hline $\begin{array}{c}\text { Rising Tide } \\
\text { North America }\end{array}$ & Refugees Welcome & MPH \\
\hline Rising Tide UK & STAR & ONE \\
\hline SNEEJ & SWRUK & Oxfam Canada \\
\hline
\end{tabular}


Table 2 - Diagnostic frames of climate justice organizations

\begin{tabular}{|c|c|}
\hline \multicolumn{2}{|r|}{ Climate Justice Movement } \\
\hline Node & Description \\
\hline $\begin{array}{l}\text { Business } \\
\text { interests }\end{array}$ & $\begin{array}{l}\text { general business practices or specific sectors created the climate problem and } \\
\text { are preventing it from being solved. }\end{array}$ \\
\hline Capitalism & $\begin{array}{l}\text { the economic system of capitalism is at the root of the problem of climate } \\
\text { change }\end{array}$ \\
\hline Climate classism & $\begin{array}{l}\text { those in lower economic classes across the North and South are negatively } \\
\text { impacted by climate change }\end{array}$ \\
\hline Climate racism & $\begin{array}{l}\text { those racialized as non-white across the North and South are negatively } \\
\text { impacted by climate change }\end{array}$ \\
\hline Colonialism & $\begin{array}{l}\text { a prior period in which the North colonized the South created inequalities for } \\
\text { which a legacy continues despite a now decolonialised relationship. }\end{array}$ \\
\hline Ecological debt & $\begin{array}{l}\text { historically, countries of the Global North were responsible for the vast majority } \\
\text { of greenhouse gas emissions and thus owe a debt to those in the Global South } \\
\text { who are suffering from climate change as a consequence }\end{array}$ \\
\hline Elites & $\begin{array}{l}\text { individuals within elite circle have produced a context that allowed for climate } \\
\text { change to occur }\end{array}$ \\
\hline 'False solutions' & $\begin{array}{l}\text { proposals to deal mitigate climate change - such as carbon trading and flexibility } \\
\text { mechanisms }{ }^{1} \text { are a major concern for justice }\end{array}$ \\
\hline $\begin{array}{l}\text { Global North } \\
\text { emissions }\end{array}$ & $\begin{array}{l}\text { high emissions from specific countries in the Global North are the reason for } \\
\text { climate change }\end{array}$ \\
\hline Governments & $\begin{array}{l}\text { states, especially large emitters from both the Global North and South, continue } \\
\text { to fail in their role of curbing the causes of climate change and agreeing to an } \\
\text { international solution }\end{array}$ \\
\hline $\begin{array}{l}\text { Indigenous } \\
\text { rights violated }\end{array}$ & indigenous lands and communities are being harmed by climate change \\
\hline Inequality & the impacts of climate change are creating greater inequalities \\
\hline Lifestyle & consumption habits have created the problem of climate change \\
\hline Neoliberalism & $\begin{array}{l}\text { neoliberalism as a system of thought and practice lies at the heart of ongoing } \\
\text { greenhouse gas emissions }\end{array}$ \\
\hline
\end{tabular}


Table 3 - Diagnostic frames of the refugee solidarity movement

\begin{tabular}{|l|l|}
\hline \multicolumn{1}{|c|}{ Node } & \multicolumn{1}{c|}{ Refugee Solidarity Movement } \\
\hline Anti-refugee public & $\begin{array}{l}\text { Public opinion and perceptions are to blame for the problems refugees } \\
\text { face. }\end{array}$ \\
\hline Arriving safe & The central problem lies in providing a safe passage to host countries. \\
\hline Bad conditions & Once in a host country, refugees suffer from bad conditions. \\
\hline Bad system & $\begin{array}{l}\text { The system to processes, manage and respond to refugees is ineffective } \\
\text { due to its needless complexity, expensiveness, short-term approach, slow } \\
\text { response, etc... }\end{array}$ \\
\hline $\begin{array}{l}\text { Dangerous and } \\
\text { vulnerable }\end{array}$ & $\begin{array}{l}\text { The migrants are escaping dangerous and traumatic situations where } \\
\text { they are vulnerable - but the reasons for these situations are left } \\
\text { ambiguous. }\end{array}$ \\
\hline EU responsibility & $\begin{array}{l}\text { The EU, rather than national governments, has a responsibility to the } \\
\text { refugees which they are not upholding }\end{array}$ \\
\hline Fairness & $\begin{array}{l}\text { For legal, historical, and/or moral reasons (specific) global north } \\
\text { countries should increase the share of refugees they host and provide } \\
\text { them with necessary support. }\end{array}$ \\
\hline $\begin{array}{l}\text { National government } \\
\text { responsibility }\end{array}$ & $\begin{array}{l}\text { National governments, rather than supranational powers, have a } \\
\text { responsibility to the refugees which they are not upholding }\end{array}$ \\
\hline Opportunities & $\begin{array}{l}\text { Refugees lack opportunities (e.g. economic, educational) they need in } \\
\text { host countries. }\end{array}$ \\
\hline Rights violated & $\begin{array}{l}\text { The refugees' rights, including human rights, are being violated and need } \\
\text { to be protected by host countries. }\end{array}$ \\
\hline Scapegoating & Elite institutions are using refugees as scapegoats for other problems \\
\hline West responsible & $\begin{array}{l}\text { The global north is partially or wholly responsible for the plight of } \\
\text { refugees. }\end{array}$ \\
\hline & \\
\hline
\end{tabular}


Table 4 - Diagnostic frames of debt relief organizations

\begin{tabular}{|c|c|}
\hline \multicolumn{2}{|r|}{ Debt Relief Movement } \\
\hline Diagnostic Frames & Description \\
\hline Business interests & $\begin{array}{l}\text { Business interests, including banks, vulture funds and other industries or } \\
\text { businesses are leading to or worsening the effects of national debts }\end{array}$ \\
\hline $\begin{array}{l}\text { Debt relief policies } \\
\text { failing }\end{array}$ & $\begin{array}{l}\text { Policies that were meant to alleviate the burdens on countries suffering } \\
\text { from debt have failed to solve the issue of the debts or have not been } \\
\text { effectively implemented. }\end{array}$ \\
\hline External shock & $\begin{array}{l}\text { Damaging effects of the global economic crisis or natural disasters, effects } \\
\text { which are largely outside the control of lender states, have made bad } \\
\text { situations become worse with regards to debt. }\end{array}$ \\
\hline Global North states & $\begin{array}{l}\text { Specific countries in the global north, or governments of the global north in } \\
\text { general, are to blame for problem of the debt or their failure to do more to } \\
\text { alleviate the problem. }\end{array}$ \\
\hline $\begin{array}{l}\text { Hinders } \\
\text { development }\end{array}$ & Debt hinders the economic development of poor countries. \\
\hline IFls & $\begin{array}{l}\text { International financial institutions (IFIs) such as the world bank and the IMF } \\
\text { are to blame for the problems caused by debt. }\end{array}$ \\
\hline Justice & $\begin{array}{l}\text { Debts are unjustly imposed and/or their consequences threaten the rights } \\
\text { of individuals within lender states. }\end{array}$ \\
\hline $\begin{array}{l}\text { Living conditions } \\
\text { poor }\end{array}$ & $\begin{array}{l}\text { Debts cause or worsen conditions for lose living in lender states, specifically } \\
\text { with regard to poverty, living standards, employment, and/or conflict. }\end{array}$ \\
\hline Loan conditions & $\begin{array}{l}\text { Loans come with conditions that are detrimental to lender states which } \\
\text { may include privatization and austerity. }\end{array}$ \\
\hline $\begin{array}{l}\text { Neoliberal } \\
\text { capitalism }\end{array}$ & $\begin{array}{l}\text { Capitalism in the form of heightened privatization and/or market } \\
\text { liberalization. }\end{array}$ \\
\hline South as problem & $\begin{array}{l}\text { Countries of the global south, and/or elites in those countries are wholly or } \\
\text { partially responsible for the problems posed by debt, often due to reckless } \\
\text { lending/spending and/or corruption. }\end{array}$ \\
\hline Sovereignty & $\begin{array}{l}\text { Debt impinges on the sovereignty of lender states, with creditors being } \\
\text { able to make decisions on their behalf. }\end{array}$ \\
\hline $\begin{array}{l}\text { Transparency and } \\
\text { accountability }\end{array}$ & $\begin{array}{l}\text { The processes of lending and spending lacks transparency and lending and } \\
\text { spending institutions are not made accountable for their actions. }\end{array}$ \\
\hline Unpayable & $\begin{array}{l}\text { Debt to growth ratios could be so high that debts become impossible to } \\
\text { pay back and are only burdensome for the debtor states. }\end{array}$ \\
\hline
\end{tabular}


Table 5 - Neo-imperialism diagnostic frames in climate justice organization websites

\begin{tabular}{|l|l|}
\hline \multicolumn{1}{|c|}{ Organization } & Neo-imperialism frame use \\
\hline Climate Justice Action & 3 \\
\hline CYCC & 0 \\
\hline Earth in Brackets & 0 \\
\hline GGJ & 10 \\
\hline GJEP & 1 \\
\hline IEN & 35 \\
\hline $\begin{array}{l}\text { Mobilization for Climate } \\
\text { Justice }\end{array}$ & 0 \\
\hline Powershift Canada & 0 \\
\hline Rising Tide UK & 5 \\
\hline RisingTideNA & 0 \\
\hline SNEEJ & 0 \\
\hline
\end{tabular}


Table 6 - Neo-imperialism diagnostic frames in debt relief organization websites

\begin{tabular}{|l|l|}
\hline \multicolumn{1}{|c|}{ Organization } & Neo-imperialism frame use \\
\hline CADTM & 11 \\
\hline DDCI & 1 \\
\hline Eurodad & 0 \\
\hline Jubilee Australia & 0 \\
\hline Jubilee Scotland & 1 \\
\hline Jubilee UK & 2 \\
\hline Jubilee USA & 2 \\
\hline MPH & 0 \\
\hline ONE & 2 \\
\hline Oxfam Canada & 1 \\
\hline
\end{tabular}

${ }^{1}$ cf. Gulbrandsen and Andersen, "NGO Influence". 